\title{
Children and adolescents on hemodialysis: attributes associated with quality of life
}

\author{
CRIANÇAS E ADOLESCENTES EM HEMODIÁLISE: ATRIBUTOS ASSOCIADOS À \\ QUALIDADE DE VIDA
}

\section{NIÑOS Y ADOLESCENTES EN HEMODIÁLISIS: ATRIBUTOS ASOCIADOS CON LA CALIDAD DE VIDA}

\author{
Isabella Schroeder Abreu', Maria Fernanda Cabral Kourrouski', Danielle Maria de Souza Serio \\ dos Santos ${ }^{2}$, Monika Bullinger ${ }^{2}$, Lucila Castanheira Nascimento ${ }^{3}$, Regina Aparecida Garcia de \\ Lima $^{4}$, Claudia Benedita dos Santos ${ }^{5}$
}

\section{ABSTRACT}

Objective: To identify quality of life impacting attributes related to health of children and adolescents with chronic renal failure, on hemodialysis, as initial step to build the specific module DISABKIDS ${ }^{\circledR}$. Method: An Exploratory descriptive study, with qualitative approach, with data collected between August of 2011 to March of 2013, through focus group analysis, with 42 participants between 8 and 18 years, their parents and caregivers. The data analysis was conducted following the thematic content, using the program Qualitative Data Analysis Software. Results: Seven themes were identified: water and food restrictions, limitations imposed by the treatment, time dedicated to treatment, change in body image related to the vascular access and growth, stigma, self-care and hope of kidney transplantation. Conclusion: Relevant aspects to the participants' experience regarding the disease and the treatment were apprehended, trying to understand how this process is associated to quality of life.

\section{DESCRIPTORS}

Child

Adolescent

Renal insufficiency chronic

Renal dialysis

Quality of life

\section{RESUMO}

Objetivo: Identificar atributos impactantes da qualidade de vida relacionada à saúde de crianças e adolescentes com insuficiência renal crônica, em hemodiálise, como etapa inicial para a construção do módulo específico DISABKIDS ${ }^{\circledR}$. Método: Estudo exploratório descritivo, de abordagem qualitativa, cujos dados foram coletados entre agosto de 2011 e março de 2013, por meio da técnica do grupo focal, com 42 participantes, entre 8 e 18 anos, e seus pais ou cuidadores. Os dados foram analisados segundo análise de conteúdo temática, com a utilização do programa Qualitative Data Analysis Software. Resultados: Foram identificados sete temas: restrições hídricas e alimentares, limitações impostas pelo tratamento, tempo dedicado ao tratamento, alteração da imagem corporal relacionada ao acesso vascular e crescimento, estigma, autocuidado e esperança do transplante renal. Conclusão: Aspectos relevantes da vivência dos participantes em relação à doença e ao tratamento foram apreendidos, buscando compreender de que forma esse processo associa-se à sua qualidade de vida.

\section{DESCRITORES \\ Criança \\ Adolescente \\ Insuficiência renal crônica \\ Diálise renal \\ Qualidade de vida}

\section{RESUMEN}

Objetivo: Identificar los atributos que afectan la calidad de vida relacionada con la salud de niños y adolescentes con insuficiencia renal crónica en hemodiálisis, como paso inicial para la construcción de un módulo específico de DISABKIDS ${ }^{\circledR}$. Método: Estudio exploratorio descriptivo, de abordaje cualitativo, cuyos datos fueron recogidos entre agosto de 2011 y marzo de 2013, a través de la técnica de grupo focal con 42 participantes entre ocho y 18 años y sus padres o cuidadores. Los datos se analizaron mediante análisis de contenido temático con la utilización del Qualitative Data Analysis Software. Resultados: Se identificaron siete temas: restricciones de agua y alimentos, limitaciones impuestas por el tratamiento, tiempo dedicado al tratamiento, alteración de la imagen corporal relacionada al acceso vascular y crecimiento, estigma, autocuidado y esperanza del trasplante de riñón. Conclusión: Se plantearon aspectos relevantes de la experiencia de los participantes en relación con su enfermedad y su tratamiento, buscando comprender de qué forma ese proceso se asocia con su calidad de vida.

\author{
DESCRIPTORES \\ Niño \\ Adolescente \\ Insuficiencia renal crónica \\ Diálisis renal \\ Calidad de vida
}

\footnotetext{
${ }^{1}$ Professor of Nursing, Midwest State University, Guarapuava, PR, Brazil. ${ }^{2}$ PhD Student, Nursing School of Ribeirão Preto, University of São Paulo. ${ }^{3}$ PhD, Professor, Institute and Polyclinic of Psychology Medicine from the Universitätsklinikum Hamburg-Eppendorf, Germany. Coordinator of the European Group DISABKIDS ${ }^{\circledR} .{ }^{4}$ Associate Professor, Department of Maternal-Infant and Public Health, Nursing School of Ribeirão Preto,University of São Paulo. ${ }^{5}$ Full Professor, Department of Maternal-Infant and Public Health, Nursing School of Ribeirão Preto, University of São Paulo. ${ }^{6}$ Associate Professor, Department of Maternal-Infant and Public Health, Nursing School of Ribeirão Preto, University of São Paulo
} 


\section{INTRODUCTION}

Health related quality of life (HRQL) is translated by the need to measure the repercussions of a determinate disease and its treatment, in accordance with people's perception about how much those factors interfere in its capacity to develop its potentialities ${ }^{(1)}$.

Studies about children and adolescents' HRQL have been awakening researchers' interest, which led to a higher development of assessment tools to evaluate those aspects.

However, there are still few or inexistent, depending on the country, validated instruments to use in this population, mainly justified by the difficulties to build tools directed to this age group with this specific intention ${ }^{(2-3)}$. Therefore, the development of a proper instrument to adequately represent domains and dimensions that are relevant for this group is needed, which, however, have been identified for adult clientele.

Chronic Renal Failure (CRF), as a chronic condition, can affect children and adolescents, with repercussion in many aspects of life, including family routine and social conviviality modifications when facing specific diet needs, commitment with the dialysis treatment, realization of invasive procedures, constant use of specific drugs and needed hospitalization due to frequent clinic alterations ${ }^{(4)}$. These factors, within others, lead children and adolescents to present emotional, physical and social alterations, influencing their HRQL.

The HRQL in children with CRF is rarely measured and, when it happens, most studies have assessed HRQL of adolescents with instruments specific for adults with CRF or, generic instruments ${ }^{(4)}$. Thus, it is important to conduct this study as a step for the construction of an instrument directed to the infant-juvenile clientele. It is added the fact of absence of specific instruments for children and adolescents with CRF, in Brazil it can be an impediment of some actions for nephrology professionals, becoming difficult the disease comprehension as disabling for everyday activities, the identification of specific complications, the treatment evaluation impact and the comparison of performed treatments ${ }^{(5)}$.

Thus, the present study objective was to identify the impactful attributes on children and adolescents' HRQL with CRF on dialysis treatment as initial step to build a HRQL measurement instrument for this population.

\section{METHOD}

A exploratory descriptive study, conducted with a qualitative research approach ${ }^{(6)}$, following the methodological referential used by the European group DISAB$\mathrm{KID}^{\circledR(7)}$, which focus is to study and develop HRQL instruments for children and adolescents in chronic conditions, in a self report version for children and adolescents at the age group 8 to 18 years old, and proxy report, designated for parents and caregivers.

The steps proposed by the group to elaborate a HRQL instrument for children and adolescents in chronic conditions are: a literature review, focal groups with the target-population, interviews with specialists, selection of items, translation, pilot study, field study and study execution ${ }^{(8)}$. In this study, the step referred to the empirical procedures is presented, comprehending the steps and the techniques for data collection with the studied public.

As technique for data collection, a Focus Group (FG) was used, based on the group interaction in discussions about the vast problematization referred to a theme or specific focus ${ }^{(9)}$.

The population was constituted by children and adolescents with 8 to 18 years with CRF and their parents or caregivers. For the FG phase, it was fundamental to define participants' selection criteria: to have CRF and to be in dialysis treatment for at least three months. To preserve the deponents' identity, capital letters were used to represent each participant. Thus, the letter $C$ represented the testimony of a child, $A$ of an adolescent, $F$ of a father, $M$ of a mother and $\mathrm{S}$, of a sibling ( 21 years). The testimonials of grandparents were represented by the letter $G$, but none of them were included here.

Fourteen FG were conducted, being two with children, five with adolescents and seven with their respective parents or caregivers; in each group there were participants of both genders. Firstly, the children and adolescent' groups were conducted, separately of their parents or caregivers. The total of participants was three components per group and the duration time was, in average, 30 minutes for children and adolescents and 60 minutes for parents or caregivers.

This research had as referential method the one used by the group DISABKIDS ${ }^{\circledR(8)}$ to conduct the FG. For each age group, 8 to 12 years and 13 to 18 years, a minimum of three to four children and adolescents of both genders and their respective parents or caregivers were selected and, a maximum of six children and adolescents of both genders and their respective parents or caregivers.

The FG were conducted between August of 2011 and March of 2013 in two hospital institutions, one in the interior of São Paulo State and another in the capital of Paraná State, both references on the assistance for children and adolescents with CRF. Those performed in the interior of São Paulo were conducted by a moderator, principal researcher and responsible by the study development, and two assistants with knowledge of the DISABKIDS $^{\circledR}$ methodology (a nurse and a pharmacist), responsible for observing the group dynamics and to assist the registration of relevant points for discussion, besides intervening in opportune moments to bring out 
or to complement questions in discussion. The groups conducted at the other institution were conducted by the principal researcher only.

To conduct the FGs, the reality and routine of the respective dialysis units were considered, besides the number of patients and their parents or caregivers. The activities were previously scheduled with the participants, in accordance with their availability. In each institution, two previous contacts with participants were done: the first aimed to meet them and to explain the conduction of groups and, the second, to schedule the groups.

The groups were distributed in accordance with hemodialysis time and the days when the patients were at the clinic; it occurred after the end of the hemodialysis sessions, in a place defined by the sector nurses, with special attention to the preservation of participant's privacy and the absence of noises on the environment that could negatively interfere the recordings' quality, once all FGs were registered in a recorder, with previous authorization by the subjects.

Anticipating the data collection, the Free Informed Consent Term reading was done, to clarify to the ethical aspects, objectives, estimated time of the group duration and how it would be conducted. With the verbal consent of children and adolescents and the consent of their parents or responsible, participation were firmed through the signature of the Free Informed Consent Term, and a copy was given to the families. At this moment, it was also asked for an authorization to record the groups. In observance with the legislation which rules research with human beings, a research protocol was submitted to the Ethics in Research Committee of the institutions where the study was conducted, being approved, respectively, by the processes HCRP 13484/10 and HPP 0962/11.

For the FGs' operationalization, all members stayed sitting as a circle, facilitating visualization, communication and interaction. Researchers, assistants and participants were introduced to the group. After, group objectives were explained and orientations about the way of conductions were given.

The discussion focus was to explore the meaning of the $\mathrm{QL}$, through the participants perceptions, based in the instrument developed by the group DISABKIDS ${ }^{\circledR}$ specifically for this purpose, denominated Interview Focus Groups. The finality was to conduct and direct the dialogue between participants in a way to make it possible to emerge aspects relevant to the theme. This instrument was validated to Brazil and it is composed by 12 open questions, through them, participants are stimulated to interact, talking and sharing their ideas about the proposed theme. Examples of the open questions are: What do you like in your life? What makes you happy? What most bothers you in your life? How the CRF affects you in your school activities or at home? The same questions were used with the groups conducted with parents or caregivers, changing only the way of how it was directed to them, with focus in their perceptions about their kids: What does your child likes more in his/her life? What makes your child happy? What most bother your child in his/her life? How the CRF affects your child's life in school activities or at home? At the end, the moderator elaborated a discussion synthesis, giving opportunity to the participants to add opinions, doubts and new ideas. At this moment, they also evaluated the performed activity.

The empiric material from all FGs had as reference the qualitative approach ${ }^{(10)}$, and for the characterization of items the thematic content analysis ${ }^{(11)}$ was used composed of: pre-analysis, correspondent to the organization phase, having as objective to operationalize and systematize the initial ideas; exploring the material, consisting in the data codification, systematically transforming and aggregating them in thematic units and, at last, the results treatment, comprehending the inference and its interpretation.

As a support tool for analysis, the program MAQXDA ${ }^{(12)}$, Computer Aided Qualitative Data Analysis Software CAQDAS was used, which supported the qualitative data analysis, with word count, key-words in the context recovery, word indexation and construction of speech analysis. In this study, the MAXQDA was used in the analysis and codification of empiric information. After reading those data, fragments of testimonials considered relevant by the researchers were selected and imported to the software, inside each correspondent domain and dimension, based in the health definition of the World Health Organization (WHO), followed by the group DISABKIDS ${ }^{\circledR}$, in which the physical, mental and social domains were considered as main categories (Table 1 ).

Table 1 - Domains and dimensions of the generic module DISABKIDS ${ }^{\circledR}$ - Ribeirão Preto, 2013

\begin{tabular}{l|c|c|l}
\hline & Domains & Dimensions & \multicolumn{1}{c}{ Concepts } \\
\hline \multirow{2}{*}{ Mental } & Independency & Autonomy; to live without problems due to the condition. \\
\cline { 3 - 4 } & Emotional & Emotional worries; anger; problems. \\
\cline { 3 - 4 } & \multirow{2}{*}{ Social } & Social Inclusion & To be accepted by others; positive social relationships \\
\cline { 3 - 4 } & Social Exclusion & Stigma; to feel excluded. \\
\cline { 2 - 4 } & \multirow{2}{*}{ Physical } & Limitation & Functional limitations; perceived health status; difficulties to sleep. \\
\cline { 3 - 4 } & Treatment & Emotional impact caused by the use of medications; constant injections, etc. \\
\hline
\end{tabular}

Children and adolescents on hemodialysis: attributes associated with quality of life Abreu IS, Kourrouski MFC, Santos DMSS, Bullinger M, Nascimento LC, Lima RAG, Santos CB 


\section{RESULTS}

Fourteen focus groups were conducted, with a total of 42 participants. Based on the reading and exploration of the resulting material from the FG testimonials, the resulting material was organized in accordance with the following themes: water and food restrictions; limitations imposed by the treatment; time dedicated to treatment; alteration in body image related to the vascular access and growth; stigma; self-care and hope of kidney transplantation.

Six children participated in the study ( 8 to 12 years) and 15 adolescents (13 to 18 years), on hemodialysis treatment, and their respective parents or caregivers, totalizing 14 mothers, three grandmothers, three fathers and one brother. The children's average age ( 8 to 12 years) was 9,8 years; within the adolescents (13 to 18 years), the average was 14,4 years and, in relation to the CRF, the majority presented a diagnosis of posterior urethral valve, followed by vesico urethral reflux and nephrotic syndrome.

\section{Water and food restrictions}

During childhood, the CRF adaptation is a daily complex process coped by children and adolescents. Difficulties permeate since the diagnosis moment until the treatment, particularly referred to coping with water and food restrictions imposed by the disease and its treatment. Let's look at some statements accordingly:

The food is bad, because it has to be without salt (C1).

I take care of the diet, I take the medication right and I control liquids a lot. I don't eat much salt and I drink very little water. It's difficult (A1).

Through the statements, it is perceived how difficult it is for those patients to cope with water and food restriction, especially the limited consumption of salt in meals, what makes the food flavor less enjoyable and attractive. The statements from children and adolescents show that, in early stages, they assume responsibilities regarding the disease and its treatment, about what they should and should not do or about what it is allowed to do or not. Prematurely, they modify their process of self-knowledge, they became mature and look for understanding and coping with their limitations.

\section{Limitations imposed by the treatment}

This theme is overall related to the questions of school evasion and losses in social activities, as playing with friends and travelling, due to the hemodialysis. For those children and adolescents, the interruption of their daily activities, many times signified to stop playing, or going to school, the forced necessity of changing habits, to stop doing what normally integrated their daily routine related to the treatment care. Some statements show those difficulties in a very clear way:
The dialysis disturbs a little, because I only go to school on Tuesdays and Thursdays mornings. But like that, I don't learn a lot (C1).

In school, there are days that I can't go, because I have to stay here in dialysis. I don't know how I haven't failed the fourth grade again! (C2).

The hemodialysis disturbs more of less our day-to-day. When I want to travel somewhere, it's harder; I can't go swimming, go to the beach (A2).

The interruption of school activities is an important factor and prominent in those children' and adolescents' lives, that was translated as missing classes, or the fact to leave early and arrive late at school due to dialysis sessions, medical consultations, exams, unexpected clinic alterations related to the dialysis, the use of medications or venous access to do the treatment, what also resulted, many times, in the need of hospitalizations.

\section{Time dedicated to the treatment}

The compromise with the treatment and, therefore, the need to wake up really early, to keep the three times per week frequency to enable the hemodialysis sessions and the four hour period to stay in the machine were emphasized by the participants. Those complaints reflect and demonstrate the illness repercussion in their lives, imposing everyday modifications.

\section{It is hard to have to stay four hours in the machine, to wake up at daybreak (A2). \\ To stay here four hours, three times per week, it's a big waste (A3).}

The child as well as the adolescent perceives their lives more limited, without possibilities to keep the activities previously done. They also perceive significant changes in their routine and in their family dynamics and note their families, especially their parents, abdicating important things in their lives to take care of them, often at the expense of family leisure.

We want to travel, [but] it is not possible, because they have to be doing the hemodialysis. You cannot make a schedule for travelling. It compromises not only their lives, but of an entire family (M1).

\section{Change in body image related to the vascular access and growth}

The question of self-image was addressed, mainly, by adolescents, due to alterations in the physical appearance, caused by the clinic condition. Those alterations are evident with the presence of a catheter or an arteriovenous fistula (AVF), vascular access used to do the hemodialysis or, still, by alterations related to growth and development, considering that CRF can result in lower height, besides metabolic and hormonal alterations. 
Their perceptions of $A V F$, related to the presence of scars and arising aneurysms from those, affect their self-image and can generate anguish feelings, not verbalized or expressed many times, making them fragile facing this experienced situation, once they need to cope with this adaptation process. Some statements allow this apprehension:

The boys don't let me play soccer in the court, they say I'll get hurt. I think they feel sorry for me, because of the catheter and the scars on my arm. They know what I have. I told them (C3).

People keep asking what is this on my neck (C2).

I was ashamed of the catheter, I didn't want to leave home, or take a bus. I only stayed in the room (A2).

He doesn't want to go to school, because he is ashamed of the catheter $(B)$

The AVF can also compromise the growth and development of those children and adolescents making them look like they have a short height, not consistent with their chronological age.

$\mathrm{He}$ [the son] also complains a lot about his growth. People say: your boy is young still, he is about ten years, and he [the son] gets embarrassed. He says: imagine me when I'm fifteen years, with this ten year old size! Ah mother, I'm embarrassed. I feel so strange! (M2).

Those statements show the presence of an embarrassment feeling associated with the physical appearance. There is fear imagining what people would say or ask about the use of a catheter, the changes on the arm where the fistula is, or still, about their stature, contributing to a negative self-image and feelings of inferiority in comparison to their peers.

\section{Stigma}

Changes in body image, as well as the development and growth retard due to the CRF, makes children and adolescents to be victims of prejudice, making them bothered and sad. They complain, especially when seen as sick, deserving pity feeling.

Many people don't understand our problem. At school it is the most difficult, with friends (C3).

When other children at school call me ill, it makes me sad (C3).

The school doesn't accept me and I want to study. I have this right (A2).

There was a girl who told me the catheter on my neck was disgusting (A2).

She feels different from the girls her age. She says: I am not normal! (M1).

At school, they named my son little balloon, because, sometimes, he used to get swollen. This is bullying (F1).
For the participants, the major difficulty is at the school environment, considered a space to socialize with other children, who demonstrate, many times, curiosity in that situation. It makes children and adolescents with CRF feel different from their peers and this feeling, can generate relationship difficulties with colleagues, besides a bad performance and school evasion.

\section{Self-care}

It is observed that although the difficulties and changes faced by those people, many of them are preoccupied with health care, especially with the vascular access. This zeal with their own body and with their health maintenance can be justified by the disease chronicity, which leads to learning to live and to get adapted with the treatment and with their new conditions:

I take care of my arm, I don't let anybody touch my fistula (C1).

During shower, I care to don't let the catheter wet. I put a plastic to protect it (A2).

The conscience and attention are important factors to cope the situation, as well as the comprehension of their experience and the conscience of risks from the disease and its treatment:

At home, I take care of myself, I care about the diet, I take the medication right, I control the liquids; I don't eat much salt nor sugar or water (C3).

I try to take my medications really right and I avoid things with potassium (A3).

\section{Hope of kidney transplantation}

The desire to recover health, independent of age group, was present in the testimonials, expressed by feelings of hope and expectancy in having kidney transplantation as a way to have their health back, to have a new kidney. It also means the possibility to detach their lives with the need of hemodialysis. The following statements illustrate this aspect:

I wanted the transplant soon, to stop coming here (A3).

I can't wait to have the transplantation! My mom will donate a kidney to me; I can't wait for the time to come (C1).

The preference for transplantation is specially related to the hope of not having more hemodialysis sessions, to eliminate the fistula punction or the discomfort caused during the arterial venous catheter manipulation and the freedom to use the time requested by the hemodialysis in a pleasurable way.

The kidney transplantation can also be related to the expectancy of improvement of their HRQL and the desire to be as any other child or adolescent, to life with relief, without the restrictions imposed by the disease, to play again things that were prohibited, to get back to school activities and to exist without the disease.
Children and adolescents on hemodialysis: attributes associated with quality of life Abreu IS, Kourrouski MFC, Santos DMSS, Bullinger M, Nascimento LC, Lima RAG, Santos CB 


\section{DISCUSSION}

The testimonials allowed to identify the main mental physical and social attributes associated with HRQL of children and adolescents with CRF in hemodialysis treatment. The results allowed the apprehension of perceptions and experiences of participants about their disease and how they affect the HRQL, showing the difficulties caused by CRF and the therapeutic. In this study, the dimensions had to be considered in general for children and adolescents, because there are no specific dimensions, once the instrument to be built is designated to the age group of 8 to 18 years. Regarding the theme water and food restrictions, the statements showed diet restrictions to be followed, that represented for a major part of patients, once it is one of the hardest steps in the treatment, as it is highly restrictive, low sodium and with low water ingestion, generating sadness, irritability, anxiety and insecurity ${ }^{(13-14)}$. Those nutritional recommendations impose changes in lifestyle, in opposition to the preferences and old eating habits ${ }^{(15)}$. Those modifications represent a challenge for those people and it can, inclusively, harm the diet adherence. It is notable in the statements that, children and adolescents as well as the parents and caregivers recognize the importance and the need to do the adequate diet, therefore, many times, they do not follow it ${ }^{(16)}$. It is known that restrictions become painful, although fundamental for the maintenance of an adequate health status ${ }^{(17-18)}$.

About the limitations imposed by the treatment, participants highlighted everyday changes, especially the interruption of school and social activities caused by hemodialysis. In a research done with children and adolescents with chronic disease it was found that it generates repercussions in patients' lives and changes their routine due to the need of frequent hospitalizations, medical consultations and exams. Thus, this routine filled with proper health demands interfere in school participation, reducing frequency, and in socialization, because it compromises self-esteem and, consequently, affects the relationship with colleagues and teachers ${ }^{(15)}$.

The school environment is highlighted as fundamental for those children and adolescents, because they build, amplify and keep necessary linkages for the development of their social interaction capacity and intellectual growth. However, due to the treatment, they need to be absent of this fruitful space, causing learning delay and losses and it can also generate social isolation ${ }^{(19-20)}$. In the parents and caregivers testimonials, it can be observed many times that school evasion comes from the trial of prioritizing activities related to the treatment, neglecting other important aspects in their everyday, for example, school activities, resulting in consecutive faults or even the abandonment. The learning process becomes, therefore, affected, as well as it aggravates the difficulty for the socialization process of those children and adolescents in the school environment. Those transformations, added to the physical and eating limitations imposed by the treatment and by the CC, directly interfere in school adaptation and in the socialization ${ }^{(14)}$, and it can cause emotional and behavioral disorders ${ }^{(21)}$.
Regarding the time dedicated to treatment, participants highlighted the need to stay four hours in the dialysis machine, with a frequency of three times per week, interfering in the daily routine. They referred to the disturbance of waking up early morning, once many of them did not live in the same city as they used to do the treatment, generally available in big centers, obligating them to travel long and constant distances. It is important to remember that some had to move to the same city as the treatment was done, due to the distance or because of personal or financial barriers that also caused changes in the family structure.

It was observed that testimonials about this theme were, in its majority, from adolescents, becoming comprehensible when considering that they experience their adolescence, a moment in which they start to interact more with colleagues, participating in activities pertinent from the age, having their own times and compromises. The time that they will dedicate to hemodialysis and the treatment demands certainly will limit this and other dimensions in their lives.

In a study about chronic renal failure children and adolescents, the results are similar to those found in this study about difficulties coped by them and their family members regarding transportation to the dialysis clinic or hospital, considering the services located in its majority, in big centers, limiting the access to hemodialysis treatment units due to the distance and transportation conditions. Those aspects are emphasized because they can directly interfere in the family financial or housing situation and make the treatment and continuous follow-up at the dialysis clinic difficult ${ }^{(15)}$.

The theme changes in body image apprehended in the testimonials, that is, of the physical appearance caused by the CRF, is, without doubts, related to the presence of the vascular access for hemodialysis and the impaired growth. The apparent venous catheter or the presence of scars and aneurisms caused by the AVF are seen as something strange in their body ${ }^{(22)}$. They feel different or inferior in comparison to other people by how the AVF or the catheter change their body, denouncing a special condition, as they can be easily seen by other people. The venous access, in special the AVF, is the first physical signal of the disease presence in the patient's body; it is the concrete meaning of their initialization in the hemodialysis ${ }^{(23)}$. It is added that the low stature in relation to the age group also generates, in those children and adolescents, feelings of embarrassment, suffering and anguish in relation to the opinion and comments of other people, prejudiced many times; those feelings can also result in isolation and low self-esteem ${ }^{(24)}$.

Self-image can be defined as the vision every person have of themselves and it comes from interactions with the social context, with other people and with oneself. Children and adolescents with chronic renal failure, due to the disease and the treatment to which they are submitted, present an impairment of their self-image, that is reflected in a sensation of difference in comparison to their 
peers, especially in adolescents ${ }^{(16)}$. They are still limited regarding the participation in activities considered pleasurable, what, one more time, can interfere negatively in the self-esteem ${ }^{(25)}$.

Another presented question in the testimonials were the stigma suffered by them, with a negative repercussion in their lives and, consequently, on the disease management. The perception of prejudice expressed in the statements demonstrate the suffering experienced by constant comments of people, especially in relation to the presence of an apparent venous catheter, by the AVF arm or, still, by the impaired growth. Situations like that happen especially at the school environment, being, therefore, victims of bullying by the way they are treated or named by colleagues. It is noteworthy that depression associated to bullying can be related to a lower adherence to treatment, interfering in self-care, possibly bringing future complications ${ }^{(25)}$. The stigma demonstrate that people, in its majority, do not know CRF, they are curious or they move away from those that are not a fit to normality patterns - attitudes that can accentuate isolation feelings experienced by those children and adolescents ${ }^{(24)}$ and compromise even more their selfesteem, once they feel discriminated.

The statements from parents and caregivers in relation to stigma, especially express their worries with people's reaction and the suffered prejudice feeling, making them adopt overprotection attitudes, something also harmful to the psychic and emotional development, considering that many start to act in a childish way.

Self-care was also found in the testimonials, showing that, although the coped difficulties, those people try to adapt to the situation, trying to control the ingestion of liquids, following the recommended diet, taking the prescribed medication and performing the needed care of the vascular access for hemodialysis. Children and adolescents with chronic disease should be aware of the importance to follow treatment therapeutic plans to which they are being submitted with the intention to prevent complications or aggravate their disease. For that, they should count with their parents or caregivers support, who also need to receive orientation from health professionals ${ }^{(26)}$.

Hope and expectation for kidney transplantation encourage and mobilize participants to look for a better HRQL. The transplantation means a possibility of not having to go to the hospital for the hemodialysis ses-

\section{REFERENCES}

1. Holmes S. Assessing the quality of life: reality or impossible dream? A discussion paper. Int J Nurs Stud. 2005; 42(4):493501. sions, besides to bring them closer of a normal life, releasing them of the suffered stigma due to changes in their physical appearance and in their lives. Those expectations for changes are highlighted by the desire of not having to be submitted to dialysis, to do activities proper for their age and to ingest foods and drinks not allowed during dialysis treatment, that is, to do common activities to most of children and adolescents ${ }^{(27)}$.

Kidney transplantation is considered the best treatment for CRF, when compared to other dialysis methods, indicating the survival of transplanted patients, adults or pediatrics, being superior to the survival of those in dialysis, what brings hope of a better quality of life ${ }^{(28)}$.

\section{CONCLUSION}

The realization of this study allowed to identify the needs and to better understand the experience of children and adolescents with CRF. The higher proximity with those patients and their parents/caregivers also allowed their subjectivities to be expressed and considered, as well as their feelings and specificities.

Facing the proposed theme for discussion in the FGs and the objective of the study, it was possible to learn relevant aspects to the comprehension of the participants' daily routine after the disease and treatment. It also allowed the comprehension of how this process is associated with the HRQL.

The identification of mental, physical and social attributes associated with the HRQL of this population open possibilities for health professionals to rethink the actual offered assistance to these patients, supporting them, aiming to minimize the diverse negative consequences form the disease/treatment. At last, they should reach a better adaptation and experience with changes, creating their own coping strategies for the imposed limitations from the chronic condition.

The utilization of FG technique made the data collection to privilege the interaction and sharing of ideas and perceptions about the proposed theme, favoring to reach the proposed objective.

The identified relevant aspects by the focus groups with children and adolescents and their parents or caregivers will contribute to the construction of an instrument to measure HRQL of this specific population.
2. Mackensen S, Bullinger M; Haemo-Qol Group. Development and testing of an instrument to assess the Quality of Life in Children with Haemophilia in Europe (Haemo-Qol). Haemophilia. 2004;10 Suppl 1:17-25.
Children and adolescents on hemodialysis: attributes associated with quality of life Abreu IS, Kourrouski MFC, Santos DMSS, Bullinger M, Nascimento LC, Lima RAG, Santos CB 
3. Bullinger M, Schmidt S, Petersen C; The DISABKIDS Group. Assessing quality of life of children with chronic health conditions and disabilities. Int J Rehabil Res. 2002; 25(3):197-206.

4. Lopes M, Koch VHK, Varni JW. Tradução e adaptação cultural do Peds QLTM ESDR para a língua portuguesa. J Bras Nefrol. 2011;33(4):448-56.

5. Shroff R, Leadermann S. Long term outcome of chronic dialysis in children. Pediatr Nephrol. 2009;24(3):463-74.

6. Polit DF, Beck CT. Fundamentos de pesquisa em enfermagem: avaliação de evidências para as práticas da enfermagem. 7ạ ed. Porto Alegre: Artmed; 2011.

7. Disabkids Goup. Translation and validation procedure: guidelines and documentation form. Leiden: The Disabkids Group; 2004

8. Baars REA. The European DISBKIDS Project: development of seven condition-specific modules to measure health related quality of life in children and adolescents. Health Qual Life Outcomes. 2005;3:70.

9. Lunardi VL, Erdmann RH, Colomé JS, Backes DS. Grupo focal como técnica de coleta e análise de dados em pesquisas qualitativas. Mundo Saúde. 2011;35(4):438-42.

10. Aquino MA, Alves EC. A pesquisa qualitativa: origens, desenvolvimento e utilização nas dissertações do PPGCI/UFPB - 2008-2012. Inf Soc Est (João Pessoa). 2012;22(1):79-100.

11. Bardin L. Análise de conteúdo. Lisboa: Edições 70; 2004.

12. MAXQDA. Qualitative Data Analisys Software [Internet]. 2013 [cited 2013 June 10]. Available from: http://www.maxqda.com/

13. Riaño-Galán I, Málaga S, Rajmil L, Ariceta G, Navarro M, Loris $C$, et al. Quality of life of adolescents with end-stage renal disease and kidney transplant. Pediatr Nephrol. 2009;24(8):1561-8.

14. Vieira SS, Dupas G, Ferreira NMLA. Doença renal crônica: conhecendo a experiência da criança. Esc Anna Nery Rev Enferm. 2009;13(1):74-83.

15. Pennafort VPS, Queiroz MVO, Jorge MSB. Children and adolescents with chronic kidney disease in an educational-therapeutic environment: support for cultural nursing care. Rev Esc Enferm USP [Internet]. 2012 [cited 2013 June 10];46(5):1057-65. Available from: http://www.scielo.br/ pdf/reeusp/v46n5/en_04.pdf

16. Diniz DP, Romano BW, Canziani MEF. Dinâmica de personalidade de crianças e adolescentes portadores de insuficiência renal crônica e submetidos à hemodiálise. J Bras Nefrol. 2006;28(1):31-8
17. Abrahão SS, Ricas J, Andrade DF, Pompeu FC, Shamahum $L$, Araujo TM, et al. Dificuldades vivenciadas pela família e pela criança/adolescente com doença renal crônica. J Bras Nefrol. 2010;32(1):18-22.

18. Oller GSAO, Ribeiro RCHM, Travagim DAS, Batista MA, Marques S, Kusumota L. Functional Independence in patients with kidney disease being treated with haemodialysis. Rev Latino Am Enferm. 2012;20(6):1033-40.

19. Frota MA, Machado JC, Martins MC, Vasconcelos VM, Landin FLP. Qualidade de vida da criança com insuficiência renal crônica. Esc Anna Nery Rev Enferm. 2010;14(3):527-33.

20. Marciano RC, Soares CMB, Diniz JSS, Lima EM, Silva JMP, Canhestro MR, et al. Transtornos mentais e qualidade de vida em crianças e adolescentes com doença renal crônica e em seus cuidadores. J Bras Nefrol. 2010;32(3):316-22.

21. Gerson AC, Wentz A, Abraham AG, Mendley SR, Hooper SR, Butler RW, et al. Health-related quality of life of children with mild to moderate chronic kidney disease. Pediatrics. 2010;125(2):e349-57.

22. Koepe GBO, Araújo STC. A percepção do cliente em hemodiálise frente à fístula arterio venosa em seu corpo. Acta Paul Enferm. 2008;21(n.esp):147-51.

23. Cabral LC, Trindade FR, Branco FMFC, Baldoino LS, Silva MLR, Lago EC. A percepção dos pacientes hemodialíticos frente à fístula arteriovenosa. Rev Interd. 2013;6(2):15-25.

24. Vieira MA, Lima RAG. Crianças e adolescentes com doença crônica: convivendo com mudanças. Rev Latino Am Enferm. 2002;10(4):552-60.

25. Pittet I, Berchtold A, Akré C, Michaud PA, Surís JC. Are adolescents with chronic conditions particularly at risk for bullying? Arch Dis Child. 2009;95(9):711-1.

26. Burille A, Zilmer JGV, Swarowsky GE, Schwartz E, Muni RM, Santos BP, et al. Os vínculos apoiadores como estratégia das famílias para lidar com a doença renal crônica e o tratamento. Rev Enferm UFPE [Internet]. 2010 [citado 2013 jun. 10];4(1):106-11. Disponível em: http://www.revista.ufpe. $\mathrm{br} /$ revistaenfermagem/index.php/revista/article/view/534

27. Setz VG, Pereira SR. O transplante renal sob a ótica de crianças portadoras de insuficiência renal crônica em tratamento dialítico: estudo de caso. Acta Paul Enferm. 2005;18(3):294300.

28. Carvalho LKAA, Lima CAA, Carneiro VA, Leite RF, Pereira AML, Pestana JO. Fatores de risco cardiovascular em pacientes pediátricos após um ano de transplante renal. Acta Paul Enferm. 2010; 23(1):114-8. 